\title{
PENERAPAN PRINSIP GREEN CONSTITUTION PADA PRODUK HUKUM DAERAH: PENDEKATAN PENYUSUNAN PERATURAN DAERAH
}

\author{
I Komang Ferdyan Julyatmikha, Fakultas Hukum Universitas Udayana, \\ E-mail: ferdyanjm@gmail.com \\ Kadek Agus Sudiarawan, Fakultas Hukum Universitas Udayana, \\ E-mail: agus_sudiarawan@unud.ac.id \\ doi: https://doi.org/10.24843/KS.2020.v09.i01.p13
}

\begin{abstract}
ABSTRAK
Tujuan penulisan artikel ini untuk memberikan pemahaman mengenai manfaat bila suatu produk hukum daerah (Peraturan Daerah) telah memiliki, mengadopsi karakter/konsep Green Constitution dan untuk mengetahui bagaimana bentuk/karakteristik suatu produk hukum daerah (Peraturan Daerah) dapat dikatakan telah menerapkan atau mengadopsi prinsip Green Constitution. Penulisan ini menggunakan metode penelitian hukum normatif dengan digunakannya pendekatan perundang-undangan (statue approach) dan pendekatan konseptual (conceptual approach). Teknik pengumpulan bahan hukum menggunakan Teknik studi literatur. Hasil studi ini menunjukkan bahwa manfaat prinsip Green constitution jika di implementasikan kedalam produk hukum daerah (peraturan daerah) dapat menjadikan lingkungan hidup tetap lestari dan terjaga, karena dianggap memiliki kedaulatan lingkungan dan hak asasinya tersendiri sehingga meningkatkan derajat dari lingkungan hidup serta dapat mewujudkan pemerintah daerah yang ecocracy dan dapat mencapai tujuan nasional dalam pembangunan berkelanjutan yang berwawasan lingkungan hidup. Karakteristik jika suatu peraturan daerah telah menerapkan prinsip Green Gonstitution dapat dilihat pada saat penyusunan peraturan tersebut dengan menggali aspek-aspek lingkungan hidup dalam naskah akademik usulan suatu peraturan daerah dan setiap pasal yang menghormati aspek kedaulatan lingkungan seperti halnya hak asasi manusia.
\end{abstract}

Kata kunci: Prinsip, Green Constitution, Kedaulatan Lingkungan, Pemerintahan Ecocracy, Naskah Akademik.

\begin{abstract}
The purpose of writing this article is to provide an understanding of the benefits if a regional legal product (Regional Regulation) already has, adopts the character / concept of the Green Constitution and to find out how the form / characteristics of a regional legal product (Regional Regulation) can be said to have implemented or adopted the Green principle. Constitution. This writing uses a normative legal research method with the use of a statutory approach (statue approach) and a conceptual approach (conceptual approach). The technique of collecting legal materials uses literature study techniques. The results of this study show that the benefits of the Green constitution principle if implemented into regional legal products (regional regulations) can make the environment sustainable and preserved, because it is considered to have environmental sovereignty and its own human rights so as to increase the degree of the environment and can create a regional government that is ecocracy and can achieve national goals in environmentally sustainable development. The characteristics if a regional regulation has applied the principle of Green Gonstitution can be seen when drafting the regulation by exploring environmental aspects in the academic text of the proposed regional regulation and each article that respects aspects of environmental sovereignty such as human rights.
\end{abstract}

Key words: Principles, Green Constitution, Environmental Sovereignty, Ecocracy Governance, Academic Manuscript. 


\section{Pendahuluan}

\subsection{Latar Belakang}

Berdasarkan Undang-undang Perlindungan Dan Pengelolaan Lingkungan Hidup menyebutkan bahwa Lingkungan Hidup adalah kesatuan ruang baik itu benda, mahluk hidup dengan keadaan dan perilakunya yang mempengaruhi alam itu sendiri serta kesejahteraan dan keberlangsungan kehidupan mahluk hidup itu sendiri. Persoalan-persoalan yang timbul menyangkut kepentingan masyarakat luas akan menimbulkan kerugian semakin banyak terjadi seperti pencemaran, kerusakan dibidang lingkungan hidup. ${ }^{1}$ Lingkungan hidup merupakan suatu hal terpenting untuk mewujudkan kehidupan sehat dalam masyarakat, tetapi pada kenyataannya Pencemaran dan kerusakan lingkungan hidup khususnya dalam ruang lingkup daerah semakin memburuk, kerusakan lingkungan merupakan pengaruh yang ditimbulkan dari perilaku manusia demi mencapai tujuan yang memiliki pengaruh negatif kepada lingkungan. ${ }^{2}$ Jika hal ini tidak dibenahi maka akan terjadinya kerusakan lingkungan hidup yang akan mengakibatkan kehidupan manusia akan tidak sehat lagi, tidak hanya di daerah saja bahkan permasalahan pencemaran lingkungan merupakan masalah global yang dialami oleh negara berkembang dan negara maju, dengan adanya perkembangan pembangunan di dunia menyebabkan terjadinya global warming (Pemanasan Global) sehingga kualitas lingkungan semakin buruk setiap tahunnya, perkembangan lingkungan hidup dalam konstitusi negara republik Indonesia telah ditegaskan dalam UUD 1945 yaitu dalam pasal 28 h ayat (1) dan Pasal 33 ayat (4) telah menitik beratkan kepada setiap orang berhak atas lingkungan hidup yang sehat, dalam mewujudkan hal tersebut maka di implementasikanlah konstitusi hijau (Green Constitution) dalam kosntitusi Indonesia sehingga dibentuknya UU tentang lingkungan hidup, tetapi masih sebagian besar pejabat pemerintah daerah yang belum mengetahui tentang Green Constitution ini. Awal mula adanya istilah Green Constitution digagas oleh seorang yang bernama Rachel Carson dengan bukunya yang pertama kali memperkenalkan istilah sustainable development yang berisi mengenai perkembangan lingkungan hidup yang diharapkan dapat mengoptimalkan secara efisien potensi sumber daya alam untuk masa kini dan masa yang akan datang. ${ }^{3}$ Dengan adanya hal tersebut mendorong PBB untuk menyelenggarakan konfrensi pertama mengenai lingkungan hidup yang dikenal dengan Stockholm declaration yang menyebabkan negara Portugal, Spanyol, dan Prancis untuk mengatur perlindungan dan pelestarian lingkungan kedalam konstitusinya. ${ }^{4}$ Pada dasarnya Green Constitution memiliki prinsip

1 Tjukup, I Ketut, Rai Asmara, Martana, Rasmadi Arsha dan Agus Sudiarawan. "Penyelesaian sengketa Lingkungan Hidup Melalui Mekanisme Acara Gugatan Perwakilan Kelompok (Class Action)". JHAPER 3, No. 2 (2017): 175-350.

2 Jazuli, Ahmad. "Dinamika Hukum Lingkungan Hidup Dan sumber Daya Alam Dalam Rangka Pembangunan Berkelanjutan (The Law Dynamics On The environmental And Natural Resources in Order To Sustainable Development)". Jurnal Rechts Vinding, Media Pembinaan Nasional 4, No. 2 (2015): 181-197.

3 Nurhayati, Nunik, "Sinkronisasi Yuridis Peraturan Perundang-Undangan Di Bidang Lingkungan Hidup Dalam Bingkai Konstitusi Hijau (Green Constitution) Undang-Undang dasar Negara Republik Indonesia Tahun 1945". Tesis Pascasarjana Prodi. Magister ilmu Hukum UNS, No. S310811007, (2014), 53-54.

$4 \quad$ Ibid. 
untuk mengkonstitusionalisasi norma hukum lingkungan hidup ke tingkat konstitusi, ${ }^{5}$ contohya seperti negara Ekuador yang menyatakan di dalam konstitusinya lingkungan hidup merupakan Fudamental Right sendiri yang harus disetarakan dengan HAM. ${ }^{6}$ Dengan adanya penempatan pengaturan hak asasi lingkungan kedalam konstitusi sebuah negara merupakan komitmen negara tersebut dalam upaya perlindungan dan pengelolaan terhadap lingkungan hidup. ${ }^{7}$

Prinsip Green Constitution ini dapat menjadi salah satu solusi untuk mencegah dan menanggulangi masalah-masalah lingkungan pada masyarakat daerah, dengan di implementasikan konsep, karakteristik dan nilai-nilai dari konstitusi hujau (Green Constitution) diharapkan dapat terciptanya pemerintahan yang ecocracy, yang dimaksud dengan pemerintahan ecocracy adalah pemerintahan yang berdasarkan kepada prinsip-prinsip pembangunan berkelanjutan dengan berwawasan lingkungan hidup (prinsip Hijau), pembangunan yang berdasarkan prinsip hijau merupakan komitmen terhadap lingkungan sebagai aktivitas pembangunan tanpa mengorbankan kelestarian lingkungan. ${ }^{8}$

Dalam pembentukan peraturan daerah seharusnnya sudah mempertimbangkan faktor-faktor dalam melindungi lingkungan hidup tetapi hanya sebatas untuk melindunginya, untuk menjamin adanya kedaulatan lingkungan hidup dalam peraturan daerah harus diterapkannya prinsip Green Constitution agar dalam setiap peraturan daerah yang dibuat tidak hanya sebatas untuk melindungi lingkungan hidup itu sendiri tetapi juga harus adanya hak asasi lingkungan hidup yang dapat disetarakan dengan hak asasi manusia sehingga lingkungan hidup tetap terjaga dan tetap lestari.

Maka dari itu perlu adanya penerapan prinsip konstitusi hijau (Green Constitutional) dalam penyusunan suatu produk hukum daerah (Peraturan daerah), dengan adanya konsep konstitusi hijau dalam kostitusi daerah maka akan timbulnya kedaulatan lingkungan yang akan menunjang terjaganya lingkungan hidup yang sehat, dalam segi konsep dan oprasionalnya kedaulatan rakyat, kedaulatan hukum serta dengan kedaulatan lingkungan harus berjalan sejajar atau harus berjalan seimbang untuk menciptakannya sebuah kehidupan yang sehat dalam masyarakat. Maka dari itu karya ilmiah ini berjudul "PENERAPAN PRINSIP GREEN CONSTITUTION PADA PRODUK HUKUM DAERAH: PENDEKATAN PENYUSUNAN PERATURAN DAERAH".

\subsection{Rumusan Masalah}

1. Apakah manfaat bila suatu produk hukum daerah (Peraturan daerah) telah memiliki, mengadopsi karakter/konsep Green Constitusion?

5 URL: https://www.jimlyschool.com/diklat/green-constitution/, 2017, Jimly Asshiddiqie, Green Constitution, Jimly School Law And Government, Diakses Pada Tanggal 28 April 2020 Pukul 20.30 WITA.

6 Rachmi Handayani, I Gusti Ayu Ketut, "Green Constitution Sebagai Penguatan Norma Hukum Lingkungan Dan Pedoman Legal Drafting Peraturan Daerah Dalam Rangka Praktikpraktik Tata Kelola Pemerintahan Yang baik Di Daerah". Yustisia 1, No. 1 (2012): 130-144.

7 Prakoso, Lucas,"Green Constitution Indonesia (Diskursus Paradigma Pembangunan Berkelanjutan)". Jurnal Hukum dan peradilan 3, No. 2 (2014): 127-136.

8 Nurmardiansyah, Eko. "Konsep Hijau: Penerapan Green Constitution dan Green Legislation Dalam Rangka Eco-Democracy". Veritas et Justitia 01, No. 01 (2015): 183-219. 
2. Bagaimana bentuk/karakteristik suatu produk hukum daerah (Peraturan Daerah) dapat dikatakan telah menerapkan atau mengadopsi prinsip Green Constitution?

\subsection{Tujuan Penulisan}

Karya ilmiah ini memiliki tujuan untuk memberikan pemahaman tentang manfaat bila suatu produk hukum daerah (Peraturan Daerah) telah memiliki, mengadopsi karakter/konsep Green Constitution, serta untuk mengetahui bagaimana bentuk/karakteristik suatu produk hukum daerah (Peraturan Daerah) dapat dikatakan telah menerapkan atau mengadopsi prinsip Green Constitution.

\section{Metode Penelitian}

Motode penelitian hukum normatif digunakan dalam penulisan karya ilmiah ini. Metode penelitian hukum normatif merupakan metode yang meneliti hukum dari prespektif internal dengan objek penelitiannya adalah norma hukum. ${ }^{9}$ Penelitian Karya ilmiah ini menggunakan berbagai sumber bahan hukum primer, sekunder dan tersier seperti peraturan perundang-undangan, penelitian-penelitian yang telah dilakukan sebelumnya, teori hukum dan pendapat para ahli. Penelitian karya ilmiah ini menggunakan beberapa pendekatan yaitu pendekatan perundangundangan (statue approach) yang memiliki arti pendekatan dalam menelaah peraturan perundang-undangan atau aturan hukum, pendekatan konseptual (conceptual approach) yang merujuk kepada pandangan atau dokrin ilmu hukum serta konsep-konsep dalam ilmu hukum. Teknik pengumpulan bahan hukum dalam penelitian ini menggunkan Teknik studi literatur yaitu pengumpulan bahan hukum melalui sumber bahan hukum primer, sekunder dan tersier. Penelitian ini menggunakan Teknik pengolahan bahan hukum Deskripsi Kualitatif yaitu hasil penelusuran dari bahan hukum primer, sekunder dan tersier disusun secara sistematis.

\section{Hasil Dan Pembahasan}

3.1 Manfaat bila suatu produk hukum daerah (Peraturan daerah) telah memiliki, mengadopsi karakter/konsep Green Constitusion.

Lingkungan hidup merupakan suatu hal yang harus dijaga, hal tersebut menjadikan prinsip Green Constitution memiliki peran penting untuk mewujudkan terjaganya lingkungan hidup, jika dikaitkan dengan kekuasaan bernegara konsepsi kedaulatan hukum dan kedaulatan rakyat adalah suatu hal yang memiliki kekuasaan tertinggi dalam bernegara, kekuasaan tertinggi tersebut jika dikombinasikan kedalam konsep lingkungan hidup yang memiliki kedaulatannya sendiri dapat dikatakan dengan istilah Ekokrasi (ecocracy) atau kedaulatan ekologi. Dengan dikombinasikannya konsepsi lingkungan hidup kedalam konstitusi sebuah negara maka kedaulatan lingkungan hidup dapat berjalan sejajar dengan kedaulatan hukum dan kedaulatan kedaulatan rakyat, lingkungan hidup memiliki tingkatan yang sejajar dengan hak asasi manusia.

Negara di dunia yang mengimplementasikan konsepsi ekokrasi pada keutamaan Green Constitution adalah Ekuador, konstitusi Ekuador tahun 2008 secara eksplisit menyatakan bahwa diberikannya hak konstitusional sebagai subyek hukum kepada

9 Diantha, I Made Pasek, Metedologi Penelitian Hhukum Normatif Dalam Justifikasi Teori Hukum, (Jakarta, Prenada Media Group, 2016), 12. 
lingkungan hidup dalam lalu lintas hukum. ${ }^{10}$ Hal tersebut dapat diaktakan bahwa hutan, sungai, gunung, tumbuh-tumbuhan memiliki hak asasinya tersendiri, hak asasi tersebut memiliki derajat yang sejajar dengan HAM. Jika demokrasi dikatakan sebagai kekuasaan tertinggi berada ditangan rakyat, maka ekokrasi atau kedaulatan lingkungan dapat dikatakan sebagai kekuasaan tertinggi berada pada lingkungan. ${ }^{11}$ untuk terciptanya kedaulatan lingkungan dan pemerintahan yang Ekokrasi atau pemerintahan yang berprinsip kepada pembangunan yang berwawasan lingkungan maka perlu di implementasikannya prinsip Green Constitution itu kedalam konstitusinya, di daerah produk hukumnya harus di sesuaikan dengan prinsip dari Green Constitution untuk terciptanya kedaulatan lingkungan di dearah tersebut.

Di Indonesia prinsip Green Constitution sudah tercermin kedalam beberapa pasal dalam UUD 1945 yaitu: ${ }^{2}$

1. Pasal 28 ayat (1) UUD 1945 yang mencerminkan hak atas lingkungan hidup sehat, bahwa negara menghormati, menngakui dan menjunjung tinggi HAM atas lingkungan hidup.

2. Penambahan ayat pada pasal 33 UUD 1945, Yakni pada pasal 33 ayat (4) yang berkaitan dengan konsep pembangunan perekonomian nasional secara berkelanjutan dengan berwawasan lingkungan, dan uraian tersebut menunjukan bahwa prinsip green constitution telah diemplementasikan kedalam rumusan pasal dan ayat UUD 1945 pasca amandemen

Tidak hanya sebatas dalam UUD 1945 dan Undang-undang yang harus diimplementasikan prinsip dari Green Constitution ini, tetapi setiap produk hukum daerah harus dapat mengimplementasikan prinsip dari Green Constitution kedalam produk hukum didaerahnya contohnya seperti PERDA dan peraturan daerah lainnya. Manfaat adanya prinsip Green Constitution ini didalam konstitusi daerah tentunya dapat menjadikan lingkungan hidup didaerah tersebut semakin terjaga dan lestari. Dengan adanya prinsip Green Constitution yang mengacu kepada Nilai-nilai yang terkandung didalam UUD 1945 yaitu khususnya berada dalam Pasal 28 ayat (1) dan Pasal 33 Ayat (4) yaitu yang berfokus kepada hak asasi manusia terhadap pembangunan nasional yang berwawasan lingkungan dalam lingkungan hidup yang sehat. Tentu saja akan menimbulkan sebuah pemerintahan ecocracy yang memiliki wawasan lingkungan hidup dalam prinsip pembangunan berkelanjutan.

Berwawasan lingkungan hidup dalam pembangunan dapat menjamin lingkungan tetap lestari dan dapat mengurangi dampak negatif terhadap lingkungan yang disebabkan oleh pembangunan-pembangunan yang tidak memikirkan efek negatif yang akan ditimbulkan terhadap lingkungan jika pembangunan tersebut tetap dilakukan. Dalam rangka untuk mewujudkan tujuan nasional, pembangunan nasional bertujuan untuk upaya dilakukannya pembangunan berkesinambungan terhadap seluruh kehidupan berbangsa dan bernegara. ${ }^{13}$ Untuk mewujudkan tujuan dalam pembangunan nasional sangat dimungkinkan dalam pemanfaatan berlebih sumber daya yang mengakibatkan terjadinya pencemaran lingkungan dan kerusakan

10 Yusa, I Gede, dan Hermanto, Bagus. "Implementasi Green Constitution di Indonesia: Jaminan Hak Konstitusional Pembangunan Lingkungan Hidup Berkelanjutan, Implementation of Green Constitution in Indonesia; Guarantees of Constitutional Right of Sustainable Enviromental Development". Jurnal Konstitusi 15, No. 2 (2018): 306-326.

11 Ibid, 312.

12 Ibid, 312-313.

13 Ketentuan Umum, Undang-undang Nomor 17 Tahun 2007 Tentang Rencana Pembangunan Jangka Panjang Nasional Tahun 2005-2025. 
lingkungan dalam skala besar, agar hal tersebut tidak terjadi maka sangat penting dari prinsip pembangunan yang berwawasan lingkungan sehingga dapat mencapai tujuan nasional tanpa merusak lingkungan hidup itu sendiri. Konsep pembangunan negaranegara didunia termasuk indonesia yang bergantung terhadap sember daya alam yang diarahkan dalam pemerdayaannya memperhatikan kelestarian fungsi serta keseimbangan lingkungannya sehingga diharapkan dapat memberikan manfaat sebesar-besarnya. ${ }^{14}$

Adanya prinsip Green Constitution dalam sebuah peraturan daerah sangat mempengaruhi lingkungan hidup didaerah tersebut, peraturan tersebut memiliki warna hijau dikarenakan telah mengimplementasikan nilai-nilai, konsep dari Green Constitusion, dalam mewujudkan pemerintahan daerah yang ecocracy tentunya harus menerapkan terlebih dahulu prinsip dari Green Constitution kedalam konstitusi daerah tesebut, pada dasarnya pemerintahan ecocracy berpedoman kepada pembangunan dalam prinsip hijau atau dapat dikatakan bahwa pembangunan tersebut mempertimbangkan aspek lingkungan sehingga dalam pembangunan tidak menimbulkan kerusakan lingkungan. Pembangunan berkelanjutan berdasarkan pasal 1 angka 3 Undang-undang Lingkungan hidup yaitu upaya sadar dan terencana yang memadukan aspek lingkungan hidup, sosial, dan ekonomi ke dalam strategi pembangunan untuk menjamin keutuhan lingkungan hidup serta keselamatan, kemampuan, kesejahteraan, dan mutu hidup generasi masa kini dan generasi masa depan. ${ }^{15}$ Dengan adanya hal tersebut dapat dikatakan bahwa pembangunan berkelanjutan dapat dilaksanakan tanpa adanya kerusakan lingkungan, ini merupakan suatu contoh dari penerapan prinsip Green Constitution itu sendiri, sehingga penerapan prinsip terasebut dalam produk hukum daerah dapat mencapai tujuan pembangunan nasional tanpa merusak lingkungan hidup didaerah tersebut, lingkungan hidup tetap lestari dan tetap sehat dalam kehidupan masyarakat.

Prinsip Green Constitution penerapannya dalam Produk hukum daerah tidak hanya demi mencapai tujuan nasional dalam pembangunan berkelanjutan, prinsip tersebut akan miningkatkan derajat dari lingkungan hidup itu sendiri, dalam penerapannya kedalam konstitusi daerah lingkungan hidup tidak hanya diperlakukan untuk dilindungi saja tetapi lingkungan hidup memiliki kedaulatannya sendiri atau dapat dikatakan bahwa lingkungan hidup memiliki hak asasinya tersendiri, dengan adanya kedaulatan lingkungan ini maka dapat disetarakan dengan hak asasi manusia sehingga lingkungan hidup dapat tumbuh dan berkembang seperti halnya manusia. Dengan adanya kedaulatan lingkungan tersebut maka lingkungan hidup dapat dipastikan tetap lestari dan tetap sehat walaupun dalam mencapai tujuan nasional sangat dimungkinkan untuk menggunakan sumber daya secara berlebihan, secara kualitas dan kuantitas ketersediaan sember daya alam tidak merata sedangkan kegiatan pembangunan membutuhkan sumber daya alam yang terus meningkat dan kegitan tersebut memiliki resiko terjadinya kerusakan dan pemcemaran lingkungan yang menyebabkan terjadinya penurunan produktivitas lingkungan tersebut dan pada

14 Ria Siombo, Marhaeni. "Kearifan Lokal Dalam Perspektif Hukum Lingkungan". Jurnal hukum 18, No. 3 (2011): 428-443.

15 Undang-undang Nomor 39 Tahun 2009 Tentang Perlindungan dan Pengelolaan Lingkungan Hidup. 
akhirnya menjadi beban sosial. ${ }^{16}$ Hal ini mewajibkan jika dalam pembangunan berwawasan lingkungan harus diikuti oleh kedaulatan lingkungan/ hak asasi lingkungan hidup sehingga dapat dipastikan jika lingkungan tetap lestari dalam pembangunan nasional. Hal ini tercermin pada pasal 33 ayat (4) UUD 1945 dimana hak asasi manusia untuk hidup didalam lingkungan hidup yang sehat, untuk mencapai hal tersebut maka lingkungan hidup harus dapat disejajarkan dengan hak asasi manusia, dengan kata lain kedaulatan lingkungan atau hak asasi lingkungan hidup harus diterapkan kedalam peraturan produk hukum daerah denagan diimplementasikan prinsip Green Constitution itu sendiri. Pada alam diakui adanya kekuasaan dan hak-hak asasinya sendiri yang tidak boleh dilanggar oleh siapapun (inalienable right) yang artinya alam diakui memiliki kedaulatannya sendiri. ${ }^{17}$ Pada dasarnya UUD 1945 sudah dapat dikatakan menerapkan prinsip Green Constitution dikarenakan kedaulatan lingkungan sudah terkandung didalamnya, tetapi tidak cukup hanya UUD 1945 saja, produk hukum daerah juga harus dapat menerapkan prinsip Green Constitution demi menjamin lingkungan hidup didaerahnya tetap terjaga dan sehat sehingga dapat memenuhi kebutuhan masyarakat untuk hidup dalam lingkungan hidup yang sehat.

\subsection{Bentuk/Karakteristik Suatu Produk Hukum Daerah (Peraturan Daerah) Dapat Dikatakan Telah Menerapkan Atau Mengadopsi Prinsip Green Constitution.}

Produk hukum suatu daerah merupakan hal terpenting dalam mengatur masyarakat demi mencapai tujuan nasional, produk hukum daerah pada kali ini lebih banyak membahas tentang Peraturan Daerah (PERDA). Berdasarkan ketentuan Undang-undang Pembentukan Peraturan Perundang-undangan menjelaskan bahwa peraturan daerah dibagi menjadi PERDA provinsi dan PERDA Kabupaten/kota. ${ }^{18}$ Pemerintah daerah memiliki kewenangannya sendiri dalam mengurus dan mengatur daerahnya sesuai dengan asas otonomi daerah yang dimiliki setiap pemerintah daerah. Kewenangan membuat kebijakan daerah sendiri untuk mengurus pemerintahannya yang mencakup seluruh kewenangan dalam bidang pemerintahan kecuali bidang agama, politik, pertahanan, luar negeri, yustisi, keamanan, fiskal nasional, dan moneter. ${ }^{19}$

Dalam penyususnan peraturan daerah agar menjadi peraturan yang baik perancang harus melakukaan beberapa hal sebagai berikut:20

1. Mengkaji secara mendalam dan komperhensif mengenai pemikiran ilmiah dan teori yang berkaitan dengan materi muatan dari rancangan peraturan yang akan dibentuk, mengarah kepada pemikiran filasofis, sosiologis dan yuridis guna mendukung perlunya atau tidak perlunya penyususnan peraturan tersebut.

16 Sastra Wibawa, I Putu. "Politik Hukum Perlindungan Dan Pengelolaan Lingkungan Menuju Ekokrasi Indonesia, Legal Politic Of Protection And Management Of Environment Heading to Indonesia Ecocracy". Kanun Jurnal Ilmu Hukum 18, No. 1 (2016): 51-68.

17 Hafidz, H. Jawade. "Ekologi Konstitusional (Green Constitution) Dan Kedaulatan Wilayah Di Indonesia". Jurnal Hukum XXVI, No. 2 (2011): 533-549.

18 Undang-undang Nomor 12 Tahun 2011 Tentang Pembentukan Peraturan Perundangundangan

19 Pasal 10 Ayat (1), Undang-undang Nomor 23 Tahun 2014 Tentang Pemerintahan Daerah.

20 Wija Atmaja, Gede Marhaendra. "Teknik Penyusunan Peraturan Daerah". Simaloka Penyususnan Produk Hukum Daerah Fakultas Hukum Universitas Udayana (2017): 3-4. 
2. Menggunakan asas pembentukan peraturan perundang-undangan yang baik serta asas yang bersifat umum.

3. Mengaitkan kaidah hukum yang sudah ada kepada peraturan perundangundangan sehingga peraturan yang akan dibentuk memiliki dasar hukum formal dan dasar hukum materiil.

4. Memiliki pengalaman dalam penyusunan suatu produk hukum, dan mengetahui mengenai kebutuhan hukum masyarakat dan pemerintahan.

Dalam penyususnannya peraturan daerah memiliki karakteristik untuk mengatur masyarakat dengan pemerintah daerah dan pelaku usahsa di daerah tersebut, Perda tidak hanya mengatur hal-hal yang memiliki kaitan terhadap kehidupan budaya masyarakat, politik dan sosial saja, tetapi juga ekonomi daerah. ${ }^{21}$ Karakteristik peraturan daerah hanya berpedoman kepada materi muatan yang bersifat filosofis, sosiologis dan yuridis. Dari pandangan yuridis baik secara eksplisit maupun implisit landasan hukum untuk membentuk Green Policy semakin kuat atas kesadaran mengenai upaya perlingdungan lingkungan hudup dari ancaman perusakan dan pencemaran.22 Peraturan perundang-undangan dalam hal ini mengacu kepada peraturan daerah. Dalam penerapan prinsip Green Constitution pada peraturan daerah tentu saja akan mengakibatkan peraturan daerah tersebut memiliki perbedaan karakteristik tetapi tidak mengubah dari tujuan pembuatan peraturan tersebut seperti menberikan keadilan, kepastian hukum, dan kemanfaatan dalam masyarakat. Jika prinsip dari Green Constitution telah di implemantasikan kedalam peraturan daerah maka dalam penyususnannya peraturan tersebut tidak hanya mempertimbangkan aspek filosofis, sosiologis, dan yuridis saja tetapi juga mempertimbangkan aspek lingkungan hidup yang memiliki kedaulatan lingkungan, sehingga dapat dikatakan bahwa peraturan daerah tersebut memiliki warna hijau dikarenakan telah menerapkan prinsip Green Constitution dalam pembentukannya.

Materi muatan tentang lingkungan hidup ini harus digali secara mendalam dan dituangkan dalam Naskah Akademik untuk memudahkan penyusunan dari suatu peraturan daerah, Naskah Akademik memiliki peran penting dalam proses pembentukan sebuah peraturan Ketika dihadapkan pada problematika peraturan selama ini yang selalu dinilai secara umum tidak berkualitas dan tidak futuristic, tidak egaliter, tidak responsive. ${ }^{23}$ Adanya Naskah Akademik memiliki peran penting dalam setiap perancangan sebuah peraturan untuk memberikan gambaran serta menunjukan bahwa rancangan yang akan diajukan tidak didasari pada kebutuhan mendadak atau pemikiran yang tidak mendalam, dan kepentingan sesaat tetapi harus didasari dengan tujuan jelas dan sasarannya. ${ }^{24}$ Maka dari itu sangat penting jika suatu penyususnan peraturan daerah dalam penerapan prinsip Green Constitution menuangkan muatan materi tentang lingkungan hidup kedalam Naskah Akademiknya, karena Naskah Akademik merupakan dasar dari usulan penyusunan peraturan daerah itu sendiri. Penerapan prinsip Green Constitution ini tidak hanya sebatas diterapkan dalam

21 Salsabila, Rizqiaranti. "Peraturan Daerah". Fakultas Hukum Universitas Lampung, Fiat Justisia 8, No. 03 (2018): 215-227.

22 Rachmi Handayani, I Gusti Ayu Ketut. Op. Cit, 136.

23 Yarni, Meri. "Penyusunan Naskah Akademik Sesuai Ketentuan Undang-undang Nomor 12 Tahun 2011 Dalam Proses Pembentukan Peraturan Daerah". Jurnal Ilmu Hukum Universitas Jambi, (2014): 155-172.

24 Masitah, Siti. "Urgensi Naskah Akademik Dalam Pembentukan Peraturan Daerah (urgency Academic Draft In Establihment Of The Region Regulations)". Kementrian Hukum dan Ham RI, Jurnal Legislasi Indonesia 10, No. 02 (2013): 109-122. 
peraturan mengenai lingkungan hidup, tetapi peraturan-peraturan lain yang memungkinkan untuk menimbulkan pencemaran lingkungan juga harus menerapkannya contohnya seperti peraturan mengenai pengalihan fungsi lahan yang memungkinkan besar menimbulkan terjadinya pencemaran lingkungan hidup.

Dalam penyususnan peraturan daerah harus mengacu kepada asas materi penyususnan peraturan perundang-undangan seperti asas kemanusian yang mencerminkan penghormatan dan perlindungan hak asasi manusia. ${ }^{25}$ Dalam penerapan prinsip Green Constitution asas materi penyususnan peraturan daerah menggunakan asas materi kedaulatan lingkungan/hak asasi lingkungan hidup yang dapat disetarakan dengan hak asasi manusia beserta dengan asas-asas umum lainnya, jika dalam awal penyususnan Naskah akademik prinsip dari Green Constitution ini telah diterapkan maka dapat dipastikan bahwa peraturan daerah tersebut sudah menerapkan dan mengadopsi dari prinsip Green Constitution yang dimana memiliki karakteristik dalam pengaturannya mempertimbangkan aspek lingkungan hidup sebagai kedaulatan lingkungan yang harus dihormati dan dijaga seperti halnya hak asasi manusia.

Peraturan daerah yang telah mengimplementasikan prinsip dari Green Constitution setiap pasal dalam peraturan tersebut memuat aspek perlindungan lingkungan hidup, dimana setiap pasal mengandung nilai-nilai dan konsep dari Green Constitution. Adanya prinsip Green Constitution dalam peraturan daerah dapat menjaga lingkungan tidak tercemar dan rusak dikarenakan dalam pembentukannya telah mempertimbangkan aspek lingkungan hidup yang dianggap memiliki keadulatannya sendiri. Dalam Undang-undang lingkungan hidup mengatur dengan jelas pentingnya filosofis nilai-nilai hijau mutlak yang diperlukannya dalam legal drafting undangundang termasuk peraturan daerah. ${ }^{26}$ Dengan adanya Green Legislation dalam pemerinahan daerah akan mewujudkan pemerintahan tersebut menjadi pemerintahan yang hijau dan pemerintahan yang ramah terhadap lingkungan (good governance).

Kedaulatan lingkungan merupakan hal mendasar dari prinsip Green Constitution dimana penerapannya dalam peraturan daerah dapat mewujudkan pemerintah daerah yang baik. Adanya nilai-nilai dan konsep dari Green Constituition pada peraturan daerah dapat mewujudkan kehidupan masyarakat yang sehat diakrenakan karakteristik dari peraturan daerah tersebut telah mengangap bahwa lingkungan tidak hanya sebatas untuk dilindungi saja tetapi lingkungan memiliki kedaulatannya sendiri seperti halnya hak asasi manusia yang harus dihormati dan dijaga demi tercapainya tujuan nasional dalam hal wawasan lingkungan pada pembangunan yang berkelanjutan.

\section{Kesimpulan}

Kedaulatan lingkungan merupakan suatu hal mendasar dari prinsip Green Constitution, manfaat prinsip Green Constitution dalam penerapannya kepada produk hukum daerah dapat mencipt akan pemerintahan yang ecocracy dengan berprinsip

25 Fatkhul Muin, Absori, "Penyususnan Peraturan Daerah Dalam Kerangka Otonomi Daerah: Suatu Tinjauan Terhadap Pembentukan Perda Yang Aspiratif". Program Doktor Ilmu Hukum Universitas Muhammadiyah Surakarta, Prosiding Konferensi Nasional Ke-4, ISBN: 978-602-19568-1-6, (2016): 265-273.

26 Rachmi Handayani, I Gusti Ketut. "Pembentukan Peraturan Daerah Berbasis Lingkungan Dalam Rangka mewujudkan Praktik-Praktik Good Governance Di Daerah". Fakultas hukum Universitas Sebelas Maret, Yustisia 2, No. 1 (2013): 66-73. 
pada pembangunan berkelanjuatan yang berwawasan lingkungan hidup dan meningkatkan derajat dari lingkungan hidup yang memiliki kedaulatannya sendiri sehingga dapat disejajarkan dengan hak asasi manusia, Nilai-nilai ini terkandung dalam UUD 1945, dengan adanya prinsip ini akan menjamin lingkungan hidup yang ada di daerah tersebut akan tetap terjaga dan lestari sehingga dapat tercapainya kebutuhan kehidupan masyarakat yang sehat dan kehidupan untuk menjaga serta melestarikan lingkungan hidup baik itu dalam pemerintahan atau masyarakatnya. Karakteristik Produk hukum daerah khususnya peraturan daerah dapat dikatakan telah mengadopsi prinsip Green Constitution jika dalam penyususnannya telah mempertimbangkan aspek lingkungan hidup yang tidak hanya sebatas untuk dilindungi tetapi aspek lingkungan hidup yang memiliki kedaulatan lingkungan dan hak asasinya tersendiri, tidak hanya sebatas asas-asas umum dalam pembentukan peraturan perundang-undangan tetapi asas kedaulatan lingkungan harus digali secara mendalam pada Naskah akademik dari peraturan daerah tersebut, jika dalam penyususnannya telah diterapkan Prinsip Green Constitution maka karakteristik tersebut dapat dilihat pada setiap pasal yang ada dalam peraturan daerah tersebut dengan menghormati aspek kedaulatan lingkungan hidup seperti halnya hak asasi manusia. Pengimplementasian dan edukasi prinsip Green Constitution terhadap produk hukum daerah (peraturan daerah) sangat berdampak positif terhadap lingkungan hidup didaerah tersebut, maka dari itu sangat disarankan kepada DPRD dalam pembentukan produk hukum daerah untuk menerapkan prinsip Green Constitution demi terciptanya kehidupan masyarakat yang sehat.

\section{DAFTAR PUSTAKA}

Buku:

Diantha, I Made Pasek. "Metedologi Penelitian Hhukum Normatif Dalam Justifikasi Teori Hukum”. (Jakarta, Prenada Media Group, 2016).

\section{Jurnal:}

Fatkhul Muin, Absori, "Penyususnan Peraturan Daerah Dalam Kerangka Otonomi

Daerah: Suatu Tinjauan Terhadap Pembentukan Perda Yang Aspiratif". Program Doktor Ilmu Hukum Universitas Muhammadiyah Surakarta, Prosiding Konferensi Nasional Ke-4, ISBN: 978-602-19568-1-6, (2016).

Hafidz, H. Jawade. "Ekologi Konstitusional (Green Constitution) dan Kedaulatan Wilayah Di Indonesia". Jurnal Hukum, Vol. XXVI, No. 2, (2011).

Jazuli, Ahmad. “Dinamika Hukum Lingkungan Hidup Dan Sumber Daya Alam Dalam Rangka Pembangunan Berkelanjutan (The Law Dynamics On The environmental And Natural Resources in Order To Sustainable Development)". Jurnal Rechts Vinding, Media Pembinaan Nasional, Vol. 4, No. 2, (2015).

Masitah, Siti. "Urgensi Naskah Akademik Dalam Pembentukan Peraturan Daerah (urgency Academic Draf In Establihment Of The Region Regulations)". Kementrian Hukum dan Ham RI, Jurnal Legislasi Indonesia, Vol. 10, No. 02, (2013).

Nurhayati, Nunik, Sinkronisasi Yuridis Peraturan Perundang-Undangan Di Bidang Lingkungan Hidup Dalam Bingkai Konstitusi Hijau (Green Constitution) UndangUndang dasar Negara Republik Indonesia Tahun 1945. Tesis Pascasarjana Prodi. Magister ilmu Hukum UNS, No.S310811007, (2014). 
Nurmardiansyah, Eko. "Kensep Hijau: Penerapan Green Constitution dan Green Legislation Dalam Rangka Eco-Democracy". Veritas et Justitia, Vol. 01, No. 01, (2015).

Prakoso, Lucas,"Green Constitution Indonesia (Diskursus Paradigma Pembangunan Berkelanjutan)". Jurnal Hukum dan peradilan 3, No. 2 (2014)

Rachmi Handayani, I Gusti Ayu Ketut, "Green Constitution Sebagai Penguatan Norma Hukum Lingkungan Dan Pedoman Legal Drafting Peraturan Daerah Dalam rangka Praktik-praktik Tata Kelola Pemerintahan Yang Baik Di Daerah". Yustisia, Vol. 1, No. 1, (2012).

Rachmi Handayani, I Gusti Ketut. "Pembentukan Peraturan Daerah Berbasis Lingkungan Dalam Rangka mewujudkan Praktik-Praktik Good Governance Di Daerah". Fakultas hukum Universitas Sebelas Maret, Yustisia, Vol. 2, No. 1, (2013).

Ria Siombo, Marhaeni. "Kearifan Lokal Dalam Perspektif Hukum Lingkungan". Jurnal hukum, Vol. 18, No. 3, (2011).

Sastra Wibawa, I Putu. "Politik Hukum Perlindungan Dan Pengelolaan Lingkungan Menuju Ekokrasi Indonesia, Legal Politic Of Protection And Management Of Environment Heading to Indonesia Ecocracy". Kanun Jurnal Ilmu Hukum, Vol.18, No. 1, (2016).

Salsabila, Rizqiaranti. "Peraturan Daerah". Fakultas Hukum Universitas Lampung, (2018).

Tjukup, I Ketut, Rai Asmara, Martana, Rasmadi Arsha dan Agus Sudiarawan. "Penyelesaian sengketa Lingkungan Hidup Melalui Mekanisme Acara Gugatan Perwakilan Kelompok (Class Action)". JHAPER, Vol. 3, No. 2, (2017).

Wija Atmaja, Gede Marhaendra. "Teknik Penyususnan Peraturan Daerah". Simaloka Penyususnan Produk Hukum Daerah Fakultas Hukum Universitas Udayana, (2017).

Yusa, I Gede, dan Hermanto, Bagus. "Implementasi Green Constitution di Indonesia:Jaminan Hak Konstitusional Pembangunan Lingkungan Hidup Berkelanjutan, Implementation of Green Constitution in Indonesia; Guarantees of Constitutional Right of Sustainable Enviromental Development". Jurnal Konstitusi, Volume 15, Nomor 2, (2018).

Yarni, Meri. "Penyusunan Naskah Akademik Sesuai ketentuan Undang-Undang Nomor 12 Tahun 2011 Dalam Proses Pembentukan Peraturan Daerah". Jurnal Ilmu Hukum Universitas Jambi, (2014).

\section{Internet:}

Law And Government, Jimly School, 2017, Green Constitution, Diakses Dari https://www.jimlyschool.com/diklat/green-constitution/ diakses pada tanggal 28 April 2020.

\section{KETENTUAN PERUNDANG-UNDANGAN}

Undang-undang Dasar Negara Republik Indonesia Tahun 1945.

Undang-undang Nomor 32 Tahun 2009 Tentang Perlindungan dan Pengelolaan Lingkungan Hidup (Lembaran Negara Republik Indonesia Tahun 2009 Nomor 140, Tambahan Lembaran Negara Republik Indonesia Nomor 5059). 
Undang-undang Nomor 12 Tahun 2011 Tentang Pembentukan Peraturan Perundangundangan (Lembaran Negara Republik Indonesia Tahun 2011 Nomor 82, Tambahan Lembaran Negara Republik Indonesia Nomor 5234).

Undang-undang Nomor 23 Tahun 2014 Tentang Pemerintahan Daerah (Lembaran Negara Republik Indonesia Tahun 2014 Nomor 244, Tambahan Lembaran Negara Republik Indonesia Nomor 5587).

Undang-undang Nomor 17 Tahun 2007 Tentang Rencana Pembangunan Jangka Panjang Nasional Tahun 2005-2025 (Lembaran Negara Republik Indonesia Tahun 2007 Nomor 33, Tambahan Lembaran Negara Republik Indonesia Nomor 4700). 